\title{
ZŁOŻONOŚĆ UWARUNKOWAŃ PRZYCZYN KATASTROFY NABRZEŻA PRZEŁADUNKOWEGO ODRY
}

\author{
Krzysztof Parylak ${ }^{凶}$, Kinga Witek \\ Wydział Inżynierii Kształtowania Środowiska i Geodezji, Uniwersytet Przyrodniczy we Wrocławiu, Wrocław
}

\begin{abstract}
STRESZCZENIE
Wybudowaną ponad 100 lat temu estakadę wykonano z kilkudziesięciu ramowych żelbetowych konstrukcji o układzie dwóch pali połączonych ryglami i płytą górną, a wzdłużnie zespolonych łączącymi je belkami. Budowla ta o wysokości $11 \mathrm{~m}$ i długości ponad $200 \mathrm{~m}$ do lat sześćdziesiątych minionego stulecia pełniła funkcję nabrzeża przeładunkowego Odry z przemieszczającym się na jej koronie lekkim dźwigiem portowym. Brak wymaganych kontroli stanu technicznego, niska jakość betonów, a przede wszystkim brak oceny uwarunkowań geotechnicznych i eksploatacyjne zaniedbania były głównymi powodami zniszczenia 110-metrowego odcinka tej konstrukcji. Nastąpiło to w okresie obniżenia poziomu wody w rzece. Wykonane po katastrofie wiercenia, sondowania i badania laboratoryjne gruntów w strefie osuwiska, jak i badania w strefach niezniszczonych, a także badania oraz pomiary obszaru zniszczeń pozwoliły na ustalenie złożonych przyczyn zniszczenia. Na podstawie zidentyfikowanej linii poślizgu i wcześniejszych incydentalnych opracowań ustalono, że strefa poślizgu zainicjowana była w niewielkiej warstwie mad przy niewielkim udziale rozpraszającego się nadciśnienia porowego. Znaczący wpływ mogła mieć nawadniająca strefę poślizgu woda odprowadzana do gruntu z przyległego budynku oraz bardzo mała wytrzymałość betonów. Utrata stateczności w jednej strefie skutkowała postępującymi zniszczeniami na przyległych odcinkach. Wykazano, że wymagane współczynniki stateczności estakady na przesunięcie i obrót nie zostały spełnione.
\end{abstract}

Słowa kluczowe: badania geotechniczne, ścianki szczelne, przebicia hydrauliczne, awarie budowlane

\section{WSTĘP}

W maju 2017 roku, w okresie podwyższonych przepływów w Kanale Odry Południowej, poniżej mostu Sikorskiego we Wrocławiu nastąpiło duże osuwisko gruntu połączone z przesunięciem i zwaleniem się do Odry ponad 110-metrowego odcinka żelbetowej estakady przeładunkowego nabrzeża.

Budowę umocnień nabrzeży Odry we Wrocławiu zapoczątkowano w XV wieku na obecnym Kanale Odry Południowej. W 1556 roku na południowym brzegu Kępy Mieszczańskiej powstał pierwszy port przeładunkowy, który rozbudowano po 1668 roku. W 1707 roku przy przystani zbudowano pierwsze magazyny i zaczął kształtować się tzw. Packhof. Po powodzi, która w 1736 roku spustoszyła Kępę Mieszczańską istniejące umocnienia musiano wymienić i w 1768 roku zastapiono je większymi. W 1822 roku na Kępie Mieszczańskiej powstały składy i magazyny towarów, a od 1850 roku przy nabrzeżu funkcjonował słynny Browar Kipkego, który transportował droga wodną surowce i wytwarzane produkty (rys. 1; Oberbaurut i Baurut, 1924).

Konstrukcje tych umocnień nabrzeży budowano wówczas intuicyjnie, tj. bez znajomości zasad mechaniki gruntów, nierzadko więc skutkowało to przypadkami zniszczeń i katastrof. W styczniu 1907 roku powstało kolejne zniszczenie (rys. 2).

\footnotetext{
${ }^{凶}$ krzysztof.parylak@upwr.edu.pl
} 


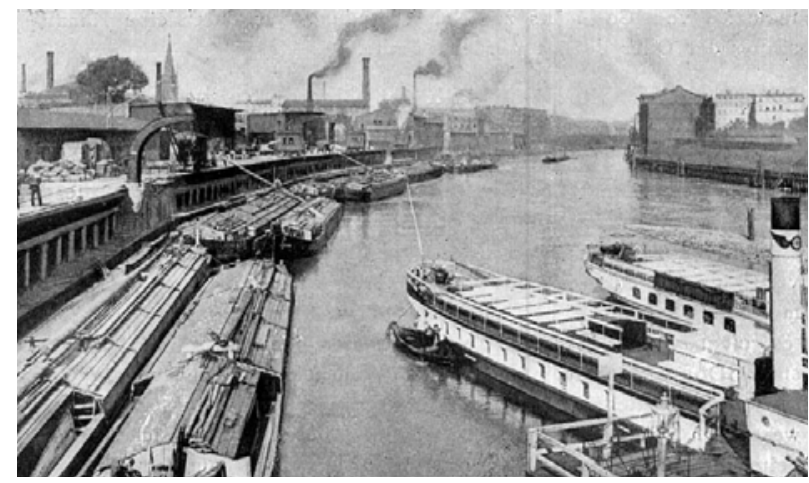

Rys. 1. Stan nabrzeża przeładunkowego na przełomie wieków XIX i XX

Fig. 1. The state of the trans-shipment wharf at the turn of the 19th and 20th centuries
W 1912 roku wykonano projekt istniejącej obecnie estakadowej żelbetowej konstrukcji umocnienia nabrzeża (rys. 3), jako układ ram złożonych z dwóch żelbetowych pali, w tym jednego o nachyleniu $1: 10$. Od góry zwieńczała je żelbetowa płyta o szerokości $3,5 \mathrm{~m}$, a dołem na poziomie oczepu żelbetowych ścian szczelnych pale dodatkowo zespolono ryglem.

Żelbetowe ściany szczelne o wymiarach $(S \times H \times L)$ $0,2 \times 0,5 \times 5,5 \mathrm{~m}$ zagłębiono na ok. 3,7 m poniżej ówczesnego dna Odry, a górą zwieńczono je wzdłużnymi belkami i płytą (Chrąchol, Dołega i Kowal, 1978). Obok estakady na powierzchni przyległego terenu ułożono granitową nawierzchnię, na której powstały spękania spoinowań umożliwiające wsiąkanie wód opadowych. Spękania te prawdopodobnie powodo-
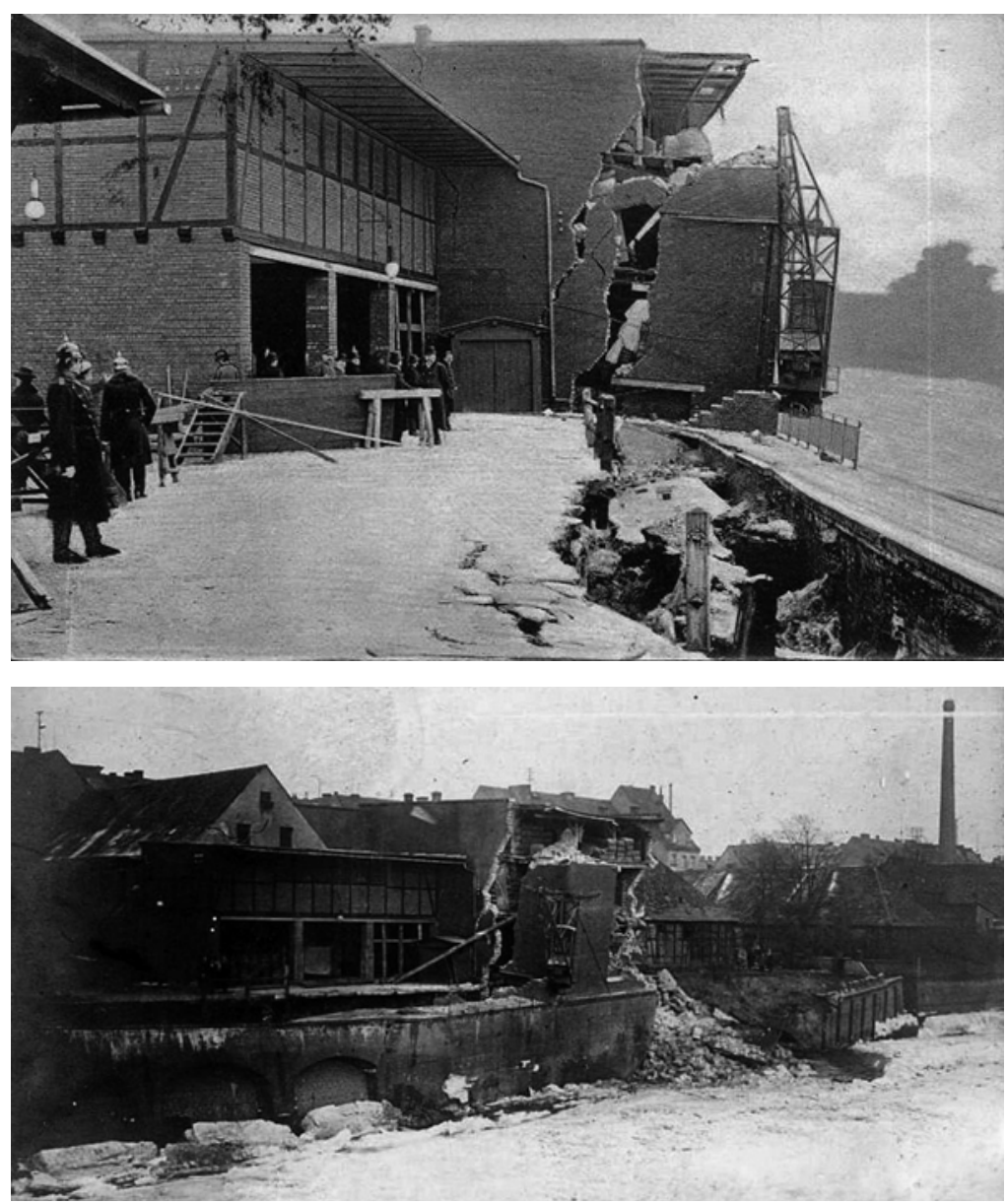

Rys. 2. Zniszczenia nabrzeża portowego Odry we Wrocławiu 29 stycznia 1907 roku

Fig. 2. Destruction of the port quay in Wroclaw on 29 January 1907 


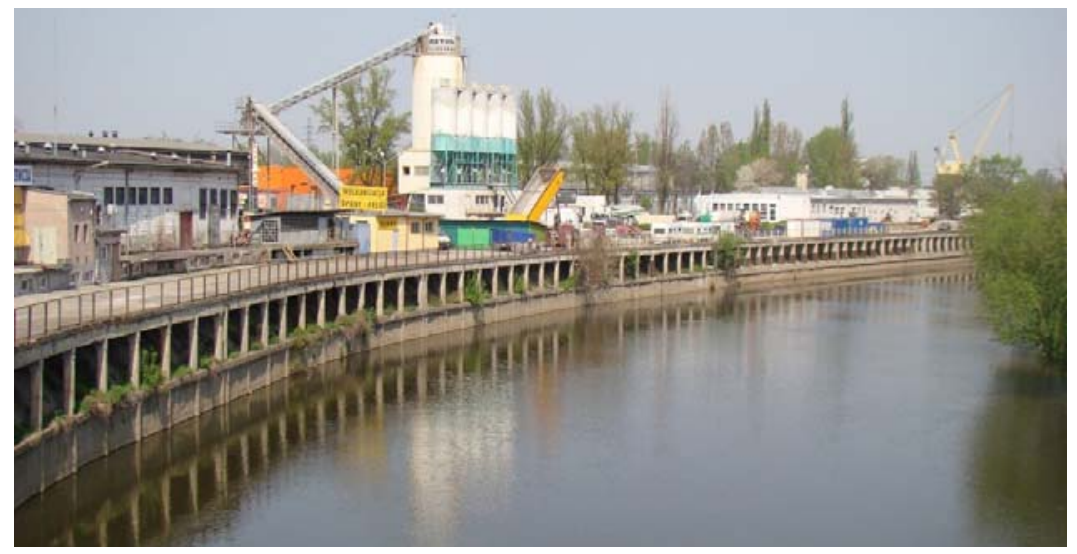

Rys. 3. Stan nabrzeża $\mathrm{z}$ okresu przed katastrofą

Fig. 3. The condition of the wharf before the catastrophe

wane były niewielkimi poziomymi przemieszczeniami estakady. Oznaki przechylania się górnej części estakady w stronę rzeki stwierdzono już w 1994 roku (rys. 3; Parylak, 1994).

\section{ZANIEDBANIA EKSPLOATACYJNE}

Administratorzy nabrzeża nie spełniali przewidzianego prawem budowlanym obowiązku wykonywania rocznych i pięcioletnich kontroli stanu technicznego konstrukcji nabrzeża (Parylak i Persona, 2017). Dotyczyło to zarówno niewykonania wymaganych badań gruntów i betonów, pomiarów przemieszczeń, inwentaryzacji stanu dna rzeki, jak i analiz stateczności konstrukcji. Wykonane w 1994 roku na potrzeby posadowienia dźwigu badania geotechniczne i oceny stanu konstrukcji wykazały, że już wówczas niektóre ramy estakady przechylone były górą w stronę rzeki, wypierając powierzchnię przyległej do nich trylinki (rys. 4; Parylak, 1994).
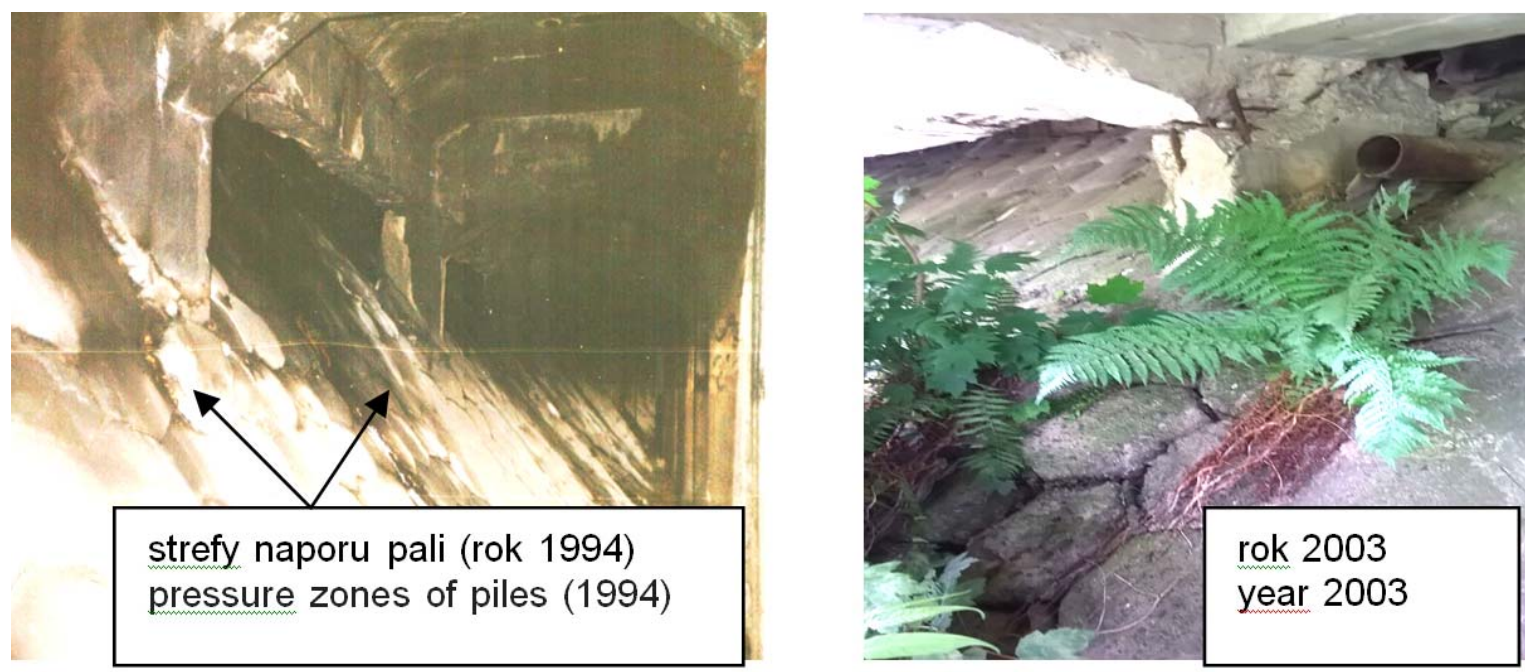

Rys. 4. Przykłady złego stanu umocnień powierzchni skarpy pod estakadą

Fig. 4. Examples of poor condition of slope surface under the flyover 
Parylak, K., Witek, K. (2018). Złożoność uwarunkowań przyczyn katastrofy nabrzeża przeładunkowego Odry. Acta Sci. Pol. Architectura, 17 (3), 91-101. doi: 10.22630/ASPA.2018.17.3.32

Potwierdzono to w późniejszym opracowaniu (Duber, Parylak i Pawłowski, 2003) dodatkowo wykazującym, że wody kanalizacji deszczowych spływały na powierzchnię umocnionej skarpy, wsiąkając w strefę parcia gruntu (rys. 4). Zignorowano także duże ubytki i spękania konstrukcji żelbetowych z odsłoniętym i skorodowanym zbrojeniem. W jednym z przekrojów stwierdzono całkowite zniszczenie pala od strony wody.

\section{OPIS KATASTROFY I CHARAKTER POWSTAŁYCH ZNISZCZEŃ}

Osuwisko to połączone ze zniszczeniem żelbetowej konstrukcji oporowej i zespolonej z nią ścianki szczelnej powstało na 115-metrowym odcinku wypukłego brzegu na dystansie od $\mathrm{km} 253+750$ do km 253+865 Odry. Zasadnicze zniszczenia polegały na zapadnięciu się estakady. Strefa maksymalnego zniszczenia miała długość $2,4 \mathrm{~m}$. Jej przesunięcie w kierunku Odry w miejscu największego osuwiska wyniosło $3,7 \mathrm{~m}$.

Nastapiło przy tym zagrożenie stateczności przyległych do osuwiska fundamentów.

\section{ANALIZA PRZYCZYN KATASTROFY}

Katastrofa nabrzeża nastąiła 3 maja 2017 roku, kiedy rzeką przepływały stany przewyższające poziom wód normalnych o $1,55 \mathrm{~m}$. Do jednej z ram przycumowane były dwie puste barki, które $w$ trakcie katastrofy uwolniły się $\mathrm{z}$ jednego $\mathrm{z}$ zaczepów. W celu ustalenia przyczyn katastrofy przeprowadzono pomiary oraz analizy możliwości oddziaływania na nabrzeże wielu czynników, w tym:

- inwentaryzację zniszczeń i pomiary geodezyjne,

- terenowe i laboratoryjne badania geotechniczne gruntów nabrzeża po obu stronach strefy zniszczenia $\mathrm{i} w$ trzech przekrojach $\mathrm{w}$ czaszy powstałego osuwiska,

- badania wytrzymałościowe betonów,

- sondowania dna rzeki i podwodną inwentaryzacje zniszczeń podwodnej części ścianek szczelnych i pali,

- analizę wpływu szybkości zmiany stanu wód Odry na możliwości rozproszenia się ciśnienia porowego,

- analizę wpływu innych czynników, w tym udziału siły od przycumowanej barki, możliwości przebicia

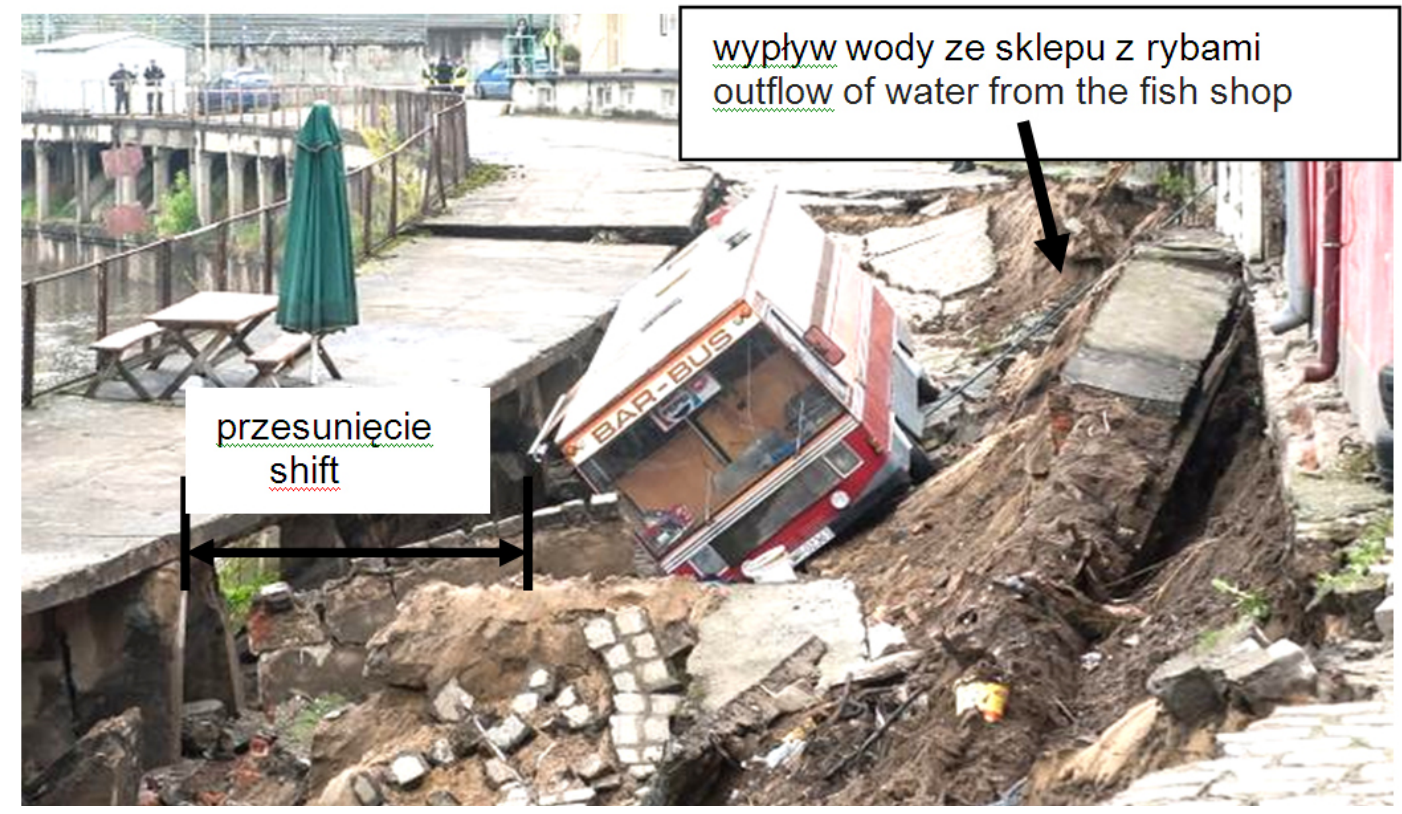

Rys. 5. Stan osuwiska w dniu katastrofy na początkowym jego odcinku

Fig. 5. The state of the landslide on the day of the disaster at its initial section 
hydraulicznego w miejscu ciagłego wypływu wody $\mathrm{z}$ budynków $\mathrm{z}$ basenami do przechowywania ryb oraz możliwości okresowego oddziaływania wypływu wody z rynien wyprowadzających wody bezpośrednio na przyległy teren (rys. 5).

\section{Analiza wpływu szybkiego obniżenia poziomu wody w rzece}

Jednym $\mathrm{z}$ mechanizmów powodujących utrate stateczności budowli piętrzących wode jest szybkie obniżenie poziomu wcześniej spiętrzonej wody w rzece po nasyceniu gruntów nabrzeża. Wobec braku danych nie do końca możliwe było ustalenie dynamiki zmian poziomu wody przed katastrofa. W kilka godzin po katastrofie stan wody był niższy o ok. $0,7 \mathrm{~m}$ od krawędzi oczepu ścian szczelnych (rys. 6). Jednakże nawet gwałtowne obniżenie tego poziomu nie powinno w tym przypadku uruchomić zniszczenia wynikającego z braku możliwości rozproszenia się nadwyżki ciśnień wody w porach i przekroczenie parametru

$$
r_{u}=B+u_{0} / \gamma H
$$

gdzie:

$r_{u}$ - stosunek ciśnienia wody w porach do ciężaru gruntu zalegającego nad powierzchnią poślizgu,

$B$ - parametr Skemptona, $u_{0}$ - ciśnienie zwierciadła wody gruntowej o wysokości $H$,

$\gamma$ - ciężar objętościowy gruntu,

$H$ - wysokość słupa wody,

$\Delta u=B \Delta \sigma_{1}-$ nadwyżka ciśnienia porowego spowodowana naprężeniem $\sigma_{1}$.

Zjawisko to stanowi częste przyczyny utraty stateczności skarp odwodnych zapór ziemnych (Bishop i Bjerrum, 1960). Jednakże przyczyny tej nie należy uznać jako jedynie sprawczej, gdyż równowagi tej nie naruszyły zmiany stanów wody w czasie 14 największych wezbrań z lat 1930-2010, z których w dwóch przypadkach zalany został przyległy teren, a pozostałe stany były niższe od największego nie więcej niż 1,6 m (Parzonka, 2014). Jednakże jedynym $\mathrm{z}$ następstw tych stanów mogło być niewielkie przechylenia estakady.

\section{Ocena wpływu potencjalnej erozji dna}

Administrator nabrzeża nie dysponował pomiarami o stanie dna przed katastrofą na odcinku zniszczonego nabrzeża.

Z rysunków projektowych z 1912 roku, a także z pomiarów sprzed 23 lat wynika, że pale od strony odwodnej zagłębione były ok. $3,7 \mathrm{~m}$ poniżej dna, a w 2017 roku powyżej miejsca katastrofy zgłębio- a

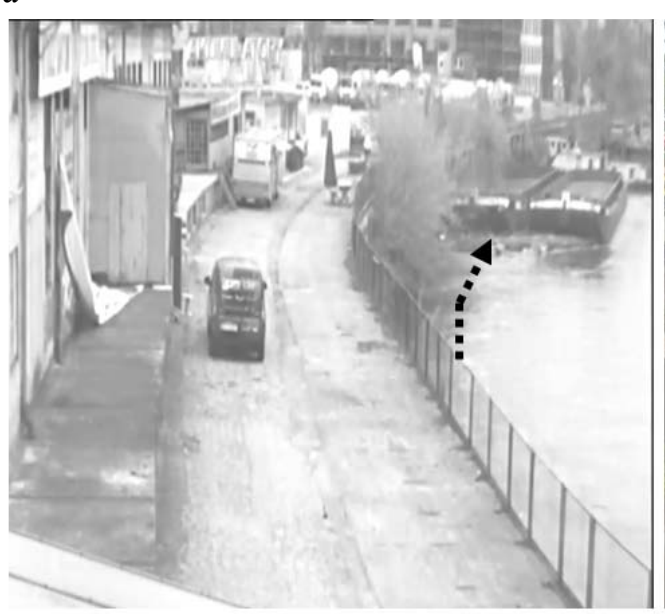

b

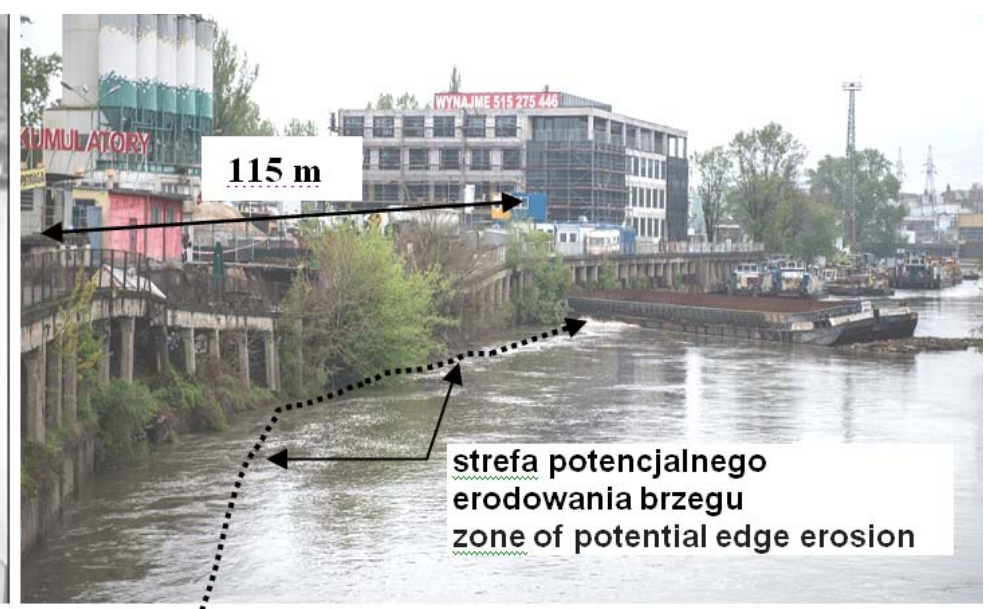

Rys. 6. Linia płynięcia głównego nurtu rzeki tuż przed katastrofą (a) i po katastrofie (b)

Fig. 6. The mainstream flow line just before the catastrophe (a) and after the catastrophe (b) 
a

b

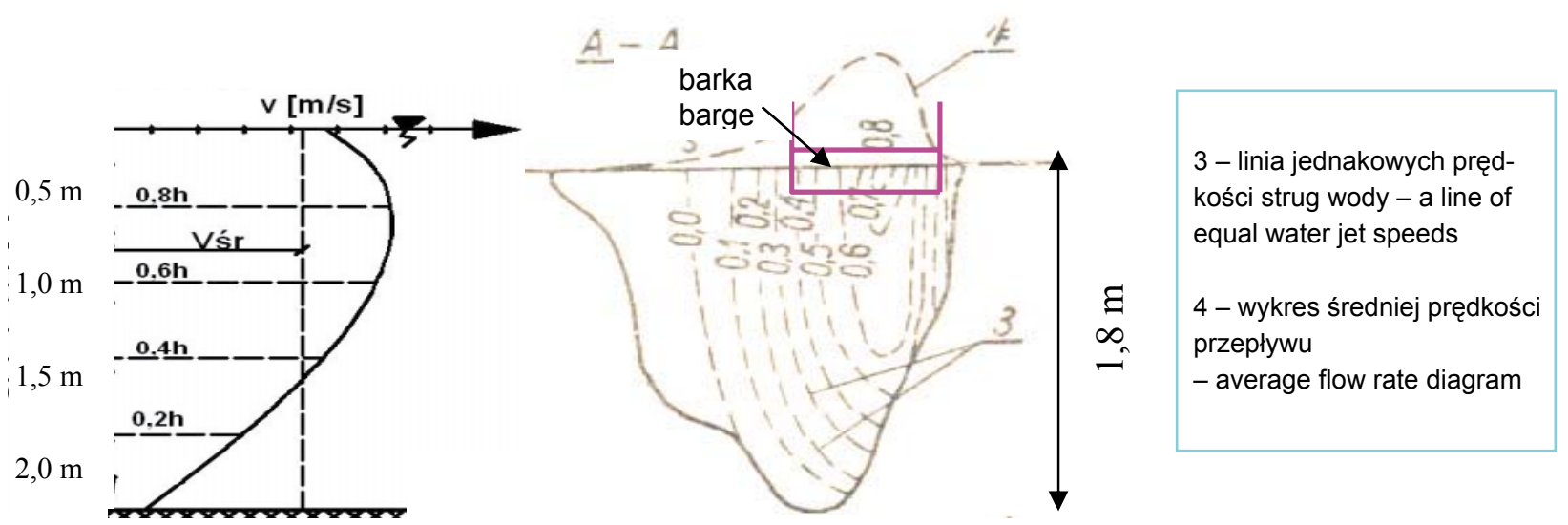

Rys. 7. Schematy rozkładów prędkości przepływu rzeki potencjalne zburzenia spowodowane obecnością barki: a - w przypadku jej lokalizacji w środku koryta rzeki; b - w przypadku jej lokalizacji na łuku rzeki

Fig. 7. Diagram of a potential disruption of the flow with the presence of the barge: $\mathrm{a}$ - in the conditions of its location in the middle of the river bed; $b$ - in the case of its location on the arch of the river

ne były tylko $1,8 \mathrm{~m}$. Pod dnem występują pospółki o $I_{D}=0,45-0,80$ (rys. 8 a).

Pomiar pierwotnego poziomu dna po katastrofie był niemożliwy, gdyż linia brzegu została przesunięta $\mathrm{w}$ stronę rzeki o $3,4 \mathrm{~m}$. W celu oceny erozyjnego działania nurtu rzeki przeanalizowano potencjalne rozkłady prędkości płynięcia wody w nurcie rzeki (rys. 7; Mamak, 1958). Przy przypowierzchniowej prędkości płynięcia wody rzędu $1,0 \mathrm{~m} \cdot \mathrm{s}^{-1}$, uwzględniając nawet zaburzający wpływ zanurzonych na $40 \mathrm{~cm}$ barek (rys. 6), energia płynięcia wody w strefie dennej jest na tyle mała, że nie powinna powodować erozji dna. Gdyby stanowiło to zagrożenie, to $\mathrm{w}$ ponad 100-letnim okresie istnienia konstrukcji niszczące skutki erozji wystapiła by wcześniej. Siła od parcia wody na barki przenoszona przez linę zamocowaną do estakady wyniosła tylko $0,4 \mathrm{kN}$.

\section{Sprawdzenie stateczności nabrzeża po powstałej linii poślizgu}

Do ustalenia warunków stateczności wykorzystano ukształtowaną po katastrofie i częściowo widoczną linię zniszczenia, w tym jej kształtu w górnej w strefie gruntów przylegających do ścian budynków. Kształt linii poślizgu w części podziemnej określono na pod- stawie analizy wykonanych sondowań, z których położenie linii wyznaczały małe wartości $I_{D}$ (rys. 8b).

Wobec braku informacji o poziomie dna Odry przed katastrofą obliczenia stateczności wykonano metodą szwedzką dla:

- wariantu I przy poziomie dna Odry, jaki można było pomierzyć na niezniszczonym odcinku nabrzeża powyżej miejsca katastrofy - 108,28 m n.p.m.;

- wariantu II przy niższym poziomie dna $(107,70 \mathrm{~m}$ n.p.m.) pomierzonym w 1994 roku (Parylak, 1994) w miejscu obecnej katastrofy.

Założono, że parametry gruntów w podłożu miejsca katastrofy były takie jak w przyległych do osuwiska odwiertach, m.in. jak w otworze 1 na rysunku 8a. Z analizy wykonanej dla wariantu I współczynnik stateczności $\left(F_{s}\right)$ wynosił 0,86 , a dla wariantu II wynosił 0,81 , czyli w każdym z tych przypadków nabrzeże powinno utracić stateczność.

O możliwości utraty stateczności wskazywały powstałe wcześniej deformacje objawiające się wypychaniem trylinki przez przemieszczającą się estakadę. Pomimo że istniały warunki wskazujące na niestateczność, nabrzeże nie uległo wcześniejszej awarii dzięki współpracy gruntu z rozstawionymi wzdłużnie co $4,1 \mathrm{~m}$ palami. 
a

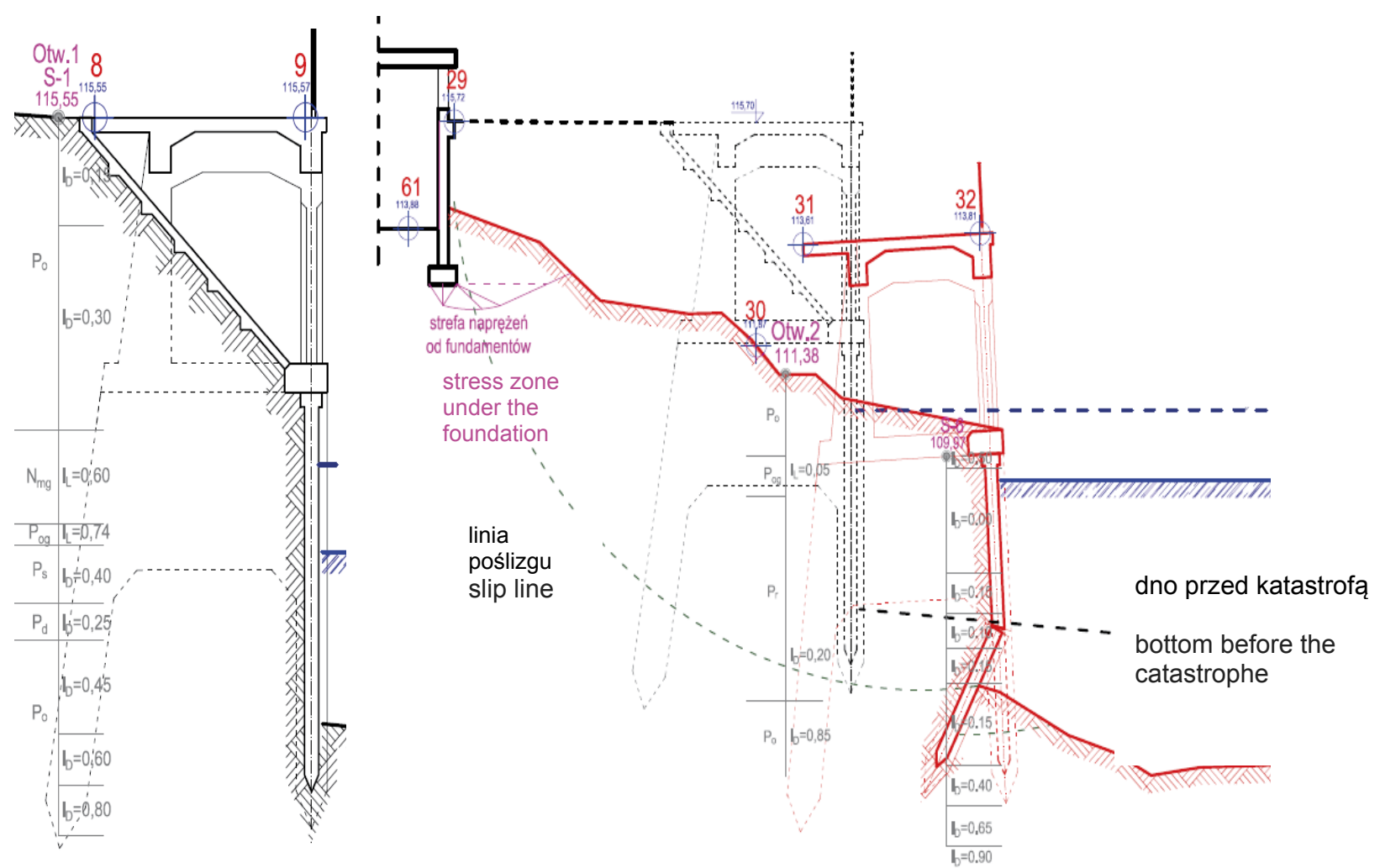

Rys. 8. Przekroje poprzeczne estakady na odcinku nabrzeża, które uległo katastrofie: $a$ - stan przed katastrofą, b - stan zniszczenia po katastrofie

Fig. 8. Cross-sections of the flyover on the section of the wharf which has been disastrous: a-state before the catastrophe, $\mathrm{b}$ - state of destruction after the catastrophe

\section{Określenie momentów zginających i głębokości zagłębienia ścian szczelnych}

Kolejnym wymaganym normą PN-EN 1997-2:2009. warunkiem sprawdzenia konstrukcji oporowej jest wyznaczenie działających na nią parć i sprawdzenie jej na przesunięcie poziome i obrót.

Obliczono siły poziome działające na estakadę zespoloną z występującą w jej dolnej części betonową ścianką szczelną. Wykorzystano je zarówno do obliczenia momentów zginających działających na estakadę i sprawdzenia wymaganej głębokości ścianek szczelnych, jak i do sprawdzenia warunków równowagi na przesunięcie poziome i na obrót.

Konstrukcję sprawdzono, stosując metodę analityczno-graficzną Bluma-Lolermeiera (Henry i Sta- rzewski, 1986; Biernatowski, Dębicki i Rossiński, 1988). Przeanalizowano ją jako pionową ścianę zagłębioną w gruncie, przyjmując za obliczeniową linię odniesienia oś belki przechodzącą wzdłuż wewnętrznego lica pala od strony odwodnej (rys. 9a). Sumaryczny wykres parć zamieniono na siły skupione i skonstruowano wielobok sznurowy, wyznaczając rozkład momentów oraz wymagane zagłębienia konstrukcji. Wykazano, że aby konstrukcję można było potraktować jako utwierdzoną $\mathrm{w}$ gruncie, umocnienie to powinno sięgać $2 \mathrm{~m}$ głębiej. Jednakże kryterium zachowania tej głębokości nie było w tym przypadku wymagane, gdyż stateczność konstrukcji warunkowały żelbetowe ramy z palem od strony lądu, rozstawione co $4,1 \mathrm{~m}$ (Henry i Starzewski, 1986). 
a

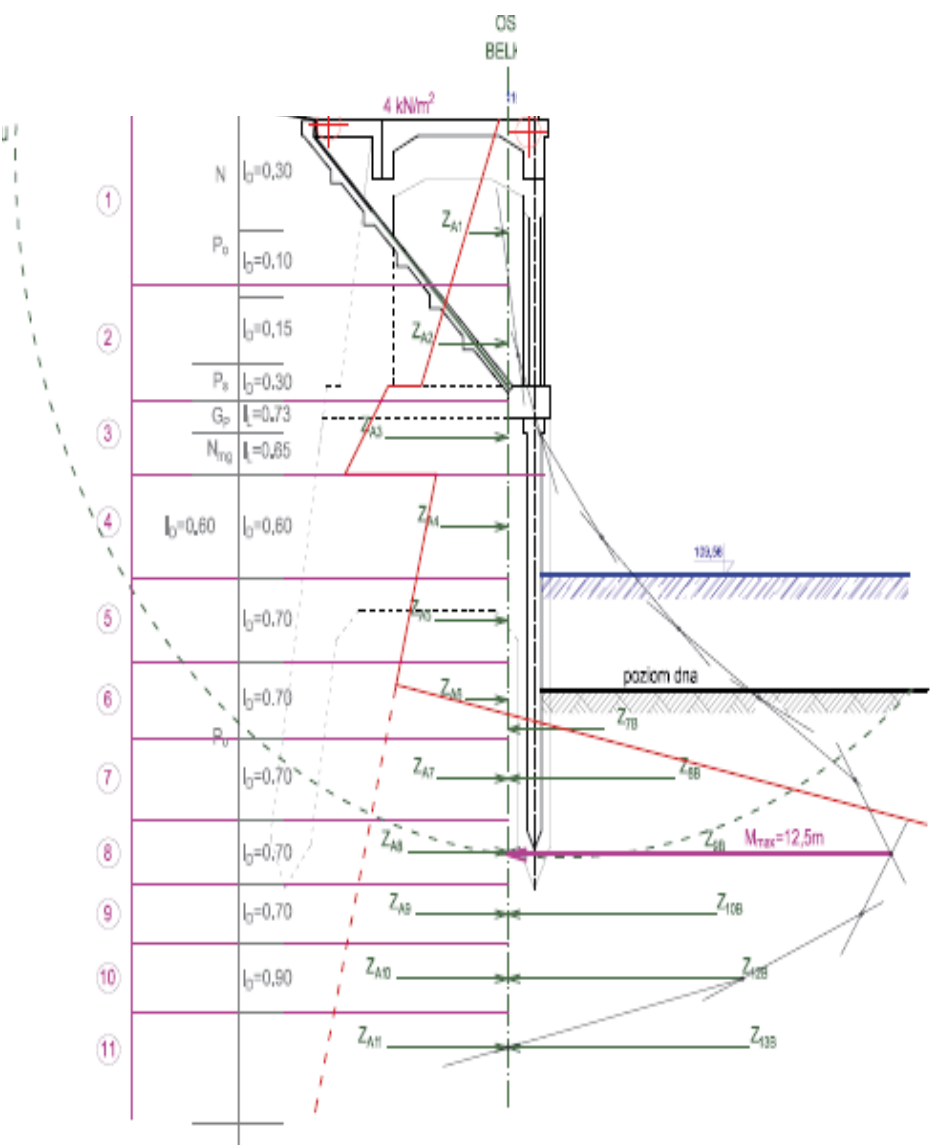

b

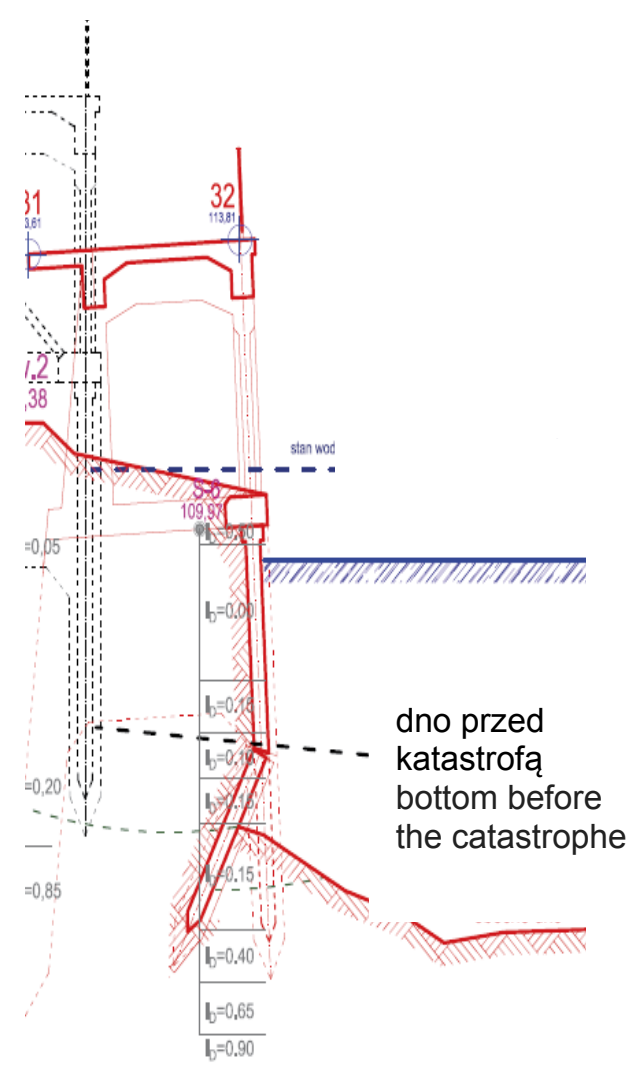

Rys. 9. Wyznaczenie momentu zginającego w miejscu złamania podwodnej części konstrukcji oporowych: a - rozkład parć i momentów zginających; b-przekrój przemieszczonej złamanej podwodnej części konstrukcji pali i ścian szczelnych w przekroju $\mathrm{V}$

Fig. 9. Determination of the bending moment in the place of fracture of the underwater part of retaining structures: $\mathrm{a}$ - distribution of pairs an bending moments; $\mathrm{b}$ - cross-section of the dislocated broken underwater part of the structure piles and tight walls in section $\mathrm{V}$

Połamanie w strefie podwodnej pali i ścianek szczelnych wyjaśniono dzięki zmierzeniu wartości i poziomu działania momentu maksymalnego. Wyniósł on $750 \mathrm{kNm}$, co pokrywa się z pomierzonym w czasie badań podwodnych poziomem złamania pali (rys. 9b).

\section{Sprawdzenie stateczności konstrukcji nabrzeża na przesunięcie i obrót}

Dla układu sił poziomych (rys. 9a) sprawdzono stateczność estakady na przesunięcie. W analizie nie uwzględniono niewielkiego oporu tarcia wynikające- go z przesuwania się podstawy ścianki szczelnej o szerokości $0,2 \mathrm{~m}$ i tarcia przesuwających się końcówek pali o wymiarach $0,4 \times 0,4 \mathrm{~m}$. Wykazano, że suma sił przesuwających $\left(\Sigma Z_{A}\right)$ wyniosła $292 \mathrm{kN}$, a suma sił utrzymujących $\left(\Sigma Z_{B}\right)$ wyniosła $244 \mathrm{kN}$. Obliczony współczynnik stateczności $\left(F_{s}\right)$ mieścił się w zakresie od 0,84 do $<1,0$. Wskazuje to, że konstrukcja ze względu na przesunięcie była niestateczna.

Sprawdzenie stateczności na obrót wykonano dla układu sił i parametrów gruntu (rys. 9a). W analizie tej obliczono stosunek momentu utrzymującego, będącego efektem działania siły skupionej reprezentującej 
Parylak, K., Witek, K. (2018). Złożoność uwarunkowań przyczyn katastrofy nabrzeża przeładunkowego Odry. Acta Sci. Pol. Architectura, 17 (3), 91-101. doi: 10.22630/ASPA.2018.17.3.32

ciężar konstrukcji żelbetowej i bryłę gruntu zawierającą się $\mathrm{w}$ obrysie ponad podstawą rozstawu pali $(3,75 \mathrm{~m})$, do momentu obracającego, który wynikał z sumy iloczynów poziomych sił skupionych działających na ramionach (stanowiących odległości tych sił od osi obrotu). Za oś obrotu przyjęto podstawę pala od strony odwodnej.

Z obliczeń wynika, że uzyskany współczynnik stateczności $\left(F_{s}=1,05\right)$ jest większy od jedności. Jednakże obliczona wartość nie spełnia wymogów rozporządzenia z 2001 roku ministra ochrony środowiska w sprawie warunków, jakim powinny odpowiadać obiekty budowle hydrotechniczne i ich usytuowanie, według którego dla normalnych warunków eksploatacji budowli wodnych $F_{s}$ powinno być nie mniejsze niż 1,3 .

\section{Ocena właściwości i stanu betonów}

$\mathrm{Na}$ katastrofę mógł mieć również wpływ stan konstrukcji nabrzeża, którą wykonano z niskiej jakości porowatego drobnoziarnistego betonu piaskowego o dużej niejednorodności i o bardzo małej przyczepności do zbrojenia (rys. 9).

Badania sklerometryczne wykazały małe wartości wytrzymałości na ściskanie rzędu 10-23 MPa, a wytrzymałość gwarantowana dla badanych elementów $\mathrm{R}_{\mathrm{b}} \mathrm{G}$ była na poziomie 2,4-7,6 MPa (PN-B-06250:1988; Parylak i Persona, 2017). Te małe wartości wytrzymałości pogarszane następstwami procesów korozji powodowały, że w istniejących stanach naprężeń konstrukcja betonowa ulegała dużym lokalnym wykruszeniom odsłaniającym pręty zbrojeniowe (rys. 10). Poza widocznym wyparciem ściany szczelnej konstrukcja ta niemal w całości została przesunięta $\mathrm{w}$ kierunku rzeki, a widoczne na rysunkach 8 i 9 złamania części podwodnych nastapiły w wyniku dalszych przemieszczeń. Należy przyjąć, że stan betonów nie mógł być powodem uruchomienia katastrofy nabrzeża. a

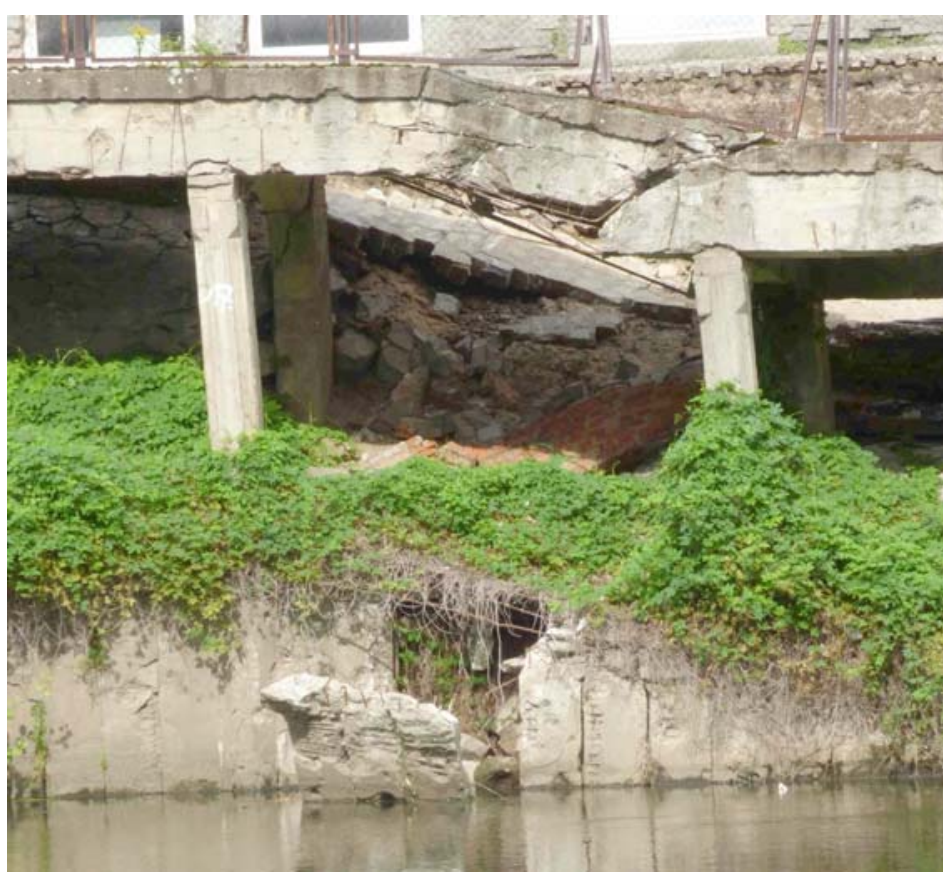

b

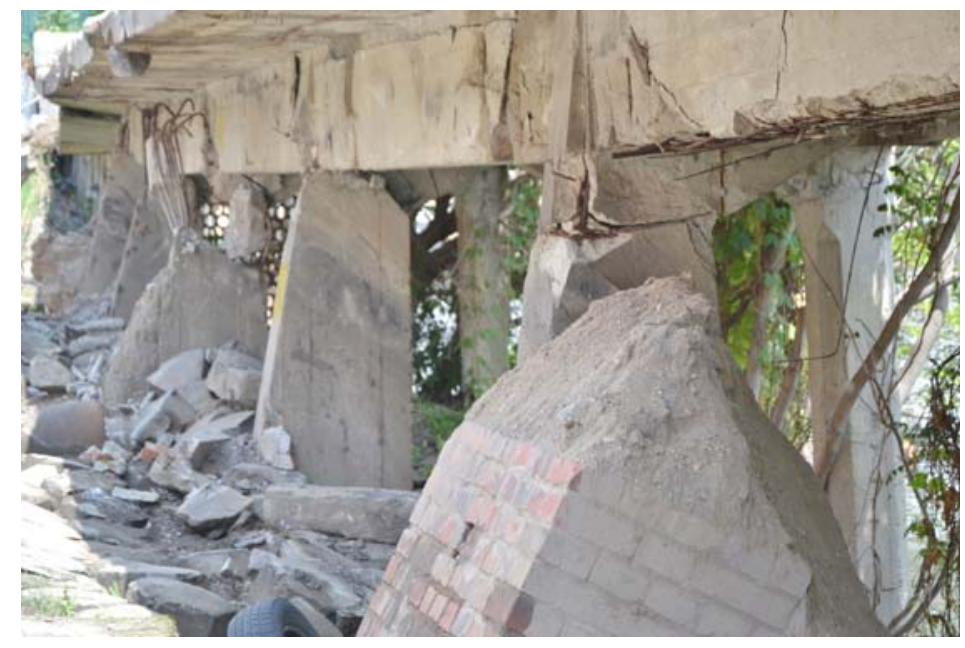

Rys. 10. Przykłady zniszczeń konstrukcji żelbetowych: a - zagłębienie estakady w górnym odcinku osuwiska (wyparte trzy brusy ścian szczelnych utraciły podparcie górą z powodu skorodowania oczepu); b - stan konstrukcji pomostu z widocznymi ubytkami zbrojenia

Fig. 10. Examples of damage to reinforced concrete structures: a - countersinking in the upper section of the landslide (repressed three concrete wall defects lost their support due to corrosion of the cap); $b$ - condition of the bridge structure with visible reinforcement defects 


\section{WNIOSKI}

1. Prawdopodobnym impulsem uruchomienia awarii było nawodnienie strefy parcia przez wodę wprowadzaną do gruntu z basenów do przechowywania ryb w przyległym budynku. Powodowało to wzrost parcia czynnego i obniżenie wartości parametrów wytrzymałości na ścinanie. Proces ten mogło ułatwić wcześniejsze podniesienie się stanu wody w Odrze, co wpłynęło także na zmniejszenie $\Phi$ i $c$ warstwy namułów. Trudno jednoznacznie ocenić wagę wpływu wyerodowania dna rzeki, co zmniejszyło by odpór gruntu u podstawy ścianek. Przy zwiększonym parciu czynnym spowodowałoby to początkowo niewielkie poziome przesunięcie estakady i ścian szczelnych, które częściowo rozluźnieniłyby grunty przyległego dna. To z kolei pomniejszało odpór gruntu i dalszą przewagę sił parcia czynnego. W tym czasie energia płynięcia nadal wynosiła już rozluźniany i erodowany grunt, w efekcie czego konstrukcja zaczęła w całości obniżać się i przesuwać w stronę dna rzeki. Kierunek przechylenia reperów 31 i 32 na rysunku $8 b$ dowodzi, że estakada nie była przewracana w stronę wody, lecz była wypierana dołem przy jednoczesnym jej zapadaniu się.

2. Udokumentowany na rysunku 9a poziom działania największego momentu zginającego pokrywający się z miejscami złamania ścianek i pali. Dowodzi to, że jeszcze przed przemieszczeniem dna brzegu rzeki końce pali i ścian szczelnych były dobrze utwierdzone w gruncie. Następowało ich łamanie, a jednocześnie przemieszczały się one z konstrukcją i zsuwającym się gruntem w stronę rzeki (maksymalnie o $3,4 \mathrm{~m}$ ).

3. Zniszczenia dalszych odcinków nabrzeża spowodowane były podobnym mechanizmem uruchamianym $\mathrm{w}$ miarę erozyjnego działania wody po miejscowym wyerodowaniu dna.

4. Katastrofa powstała w następstwie pogarszających się od lat warunków stateczności budowli, wynikających z zaniedbań eksploatacyjnych, a w tym braku mogących to wykazać pomiarów, badań i wymaganych w ich wyniku przeciwdziałań.

\section{PIŚMIENNICTWO}

Biernatowski, K., Dębicki, E. i Rossiński, B. (1988). Fundamentowanie. Projektowanie i wykonawstwo. Warszawa: Arkady.

Bishop, A. i Bjerrum, L. (1960). The relevance of the triaxial test to the solution of stability problem. W Proceedings ASCE Research Conference on Shear Strength of Cohesive Soil, Colorado (strony 437-501).

Chrąchol, I., Dołega, J. i Kowal, J. (1978). Badania stanu technicznego nabrzeża rzeki Odry w obrabie miasta Wrocławia. Wrocław: Politechnika Wrocławska.

Duber, A., Parylak, K. i Pawłowski, A. (2006). Ocena techniczna konstrukcji umocnienia lewostronnego odcinka nabrzeża odcinka Odry poludniowej $w \mathrm{~km} \mathrm{253+677-}$ $-253+824$ przy ul. Dlugiej we Wroctawiu.

Henry, F. i Starzewski, K. (1986). The Design and Construction of Engineering Foundation. New York: Chapman and Hall.

Mamak, W. (1958). Regulacja rzek i potoków. Warszawa: Arkady.

Oberbaurat, V. i Baurat, R. (1924). Die Kanalisierung der Nesissemunderng bis oberhalp Breslau. Breslau: Zeitschrift für Bauwewen.

Parylak, K. (1994). Ekspertyza geotechniczna. Ocena możliwości posadowienia żurawia budowlanego $w$ rejonie pomostu przeladunkowego Odry przy ul. Dlugiej we Wroctawiu.

Parylak, K. i Persona, M. (2017). Ekspertyza ustalajaca przyczyny $i$ okoliczności katastrofy budowlanej polegajacej na uszkodzeniu nabrzeża rzeki Odry na odcinku około $100 \mathrm{~m}$ na wysokości nieruchomości położonych przy ul. Dtugiej 15 i ul. Michalczyka 3 we Wrocławiu oraz określajacej zakres czynności niezbędnych do likwidacji zagrożenia bezpieczeństwa ludzi lub mienia.

Parzonka, W. (2014). Ocena przejścia fali powodziowej w maju 2010 r. we Wrocławskim Węźle Wodnym. Acta Scientiarum Polonorum Architectura, 4, 185-202.

PN-B-06250:1988. Beton zwykły.

PN-EN 1997-2:2009. Eurokod 7 - Projektowanie geotechniczne. Część 2: Rozpoznanie i badania podłoża gruntowego.

Rozporządzenie Ministra Ochrony Środowiska $\mathrm{z}$ dnia 20 kwietnia 2007 r. w sprawie warunków, jakim powinny odpowiadać budowle hydrotechniczne i ich usytuowanie (Dz.U. $2007 \mathrm{nr}$ 21, poz. 111). 


\title{
COMPLEXITY OF CONDITIONING CATASTROPHES OF TRANSMITTING COAL OF ODRA RIVER
}

\begin{abstract}
A flyover constructed over 100 years ago was made of several dozen framework reinforced concrete structures with a two-pile. Trestle system connected by bolts and the upper plate, and longitudinally joined by connecting beams. This building, with a height of $11 \mathrm{~m}$ and a length of over $200 \mathrm{~m}$ to $1960 \mathrm{~s}$, served as a transshipment dockside quay of the Oder with a light port crane moving on its crest. Lack of required technical inspections, low concrete quality, and above all the lack of assessment of geotechnical conditions and operational neglect were the main reason for the destruction of a 110-meter section of this structure. This occurred during the period of lowering the water level in the river. The necessary geotechnical drilling, probing and laboratory tests of the lands in the landslide zone, as well as research in the non-destructive zones and measurements of the area of destruction made it possible to determine the complex causes of destruction. On the basis of the identified slip line and previous incidental studies determined that the slip surface was initiated in a small alluvial soils layer with a small contribution of dispersing pore high-pressure. The irrigation zone drained to the ground of water could have a significant impact of slip away water from the adjacent building and very low concrete strength. Damage in one zone resulted in progressive destruction on adjacent sections. It was proved that the stability factors of the estacade for sliding and overturning were not met.
\end{abstract}

Key words: geotechnical investigations, sheet piling, piping, construction failures 